\title{
Variability of energy woodchips and their economic effects
}

\author{
Arkadiusz Gendek 凶, Tomasz Nurek \\ Warsaw University of Life Sciences - SGGW, Faculty of Production Engineering, Department of Agricultural and Forestry \\ Machines, Nowoursynowska 164, 02-787 Warsaw, Poland, phone: +48 22 5934513, email: arkadiusz_gendek@sggw.pl
}

\section{Abstract}

The main aim of the work is to assess physical parameters of forest woodchips and their impact on the prices achieved by the supplier in transactions with a power plant. During fragmentation of logging residue, high content of green matter and contaminants negatively impacts the quality parameters that serve as basis for settlements. The analysis concerns data on the main parameters - water content, fuel value, sulphur and ash content - from 252 days of deliveries of forest chips to a power plant. The deliveries were realised from forested areas on an average about $340 \mathrm{~km}$ from the plant. Average water content and the resultant fuel value of forest chips was within $27-47 \%$ and 8.7-12.9 GJ $\times \mathrm{Mg}^{-1}$ (appropriately), respectively. They depend on the month in which they are delivered to the power plant. The threshold values for the above-mentioned parameters are set by the plant at a real level and the suppliers have no problems with meeting them. The parameter that is most frequently exceeded is ash content (11.5\% of cases). The settlement system does not differentiate on the basis of the transport distance but gives possibility to lower the settlement price when the quality parameters are not met but provides no reward for deliveries with parameters better than the average ones. On the basis of results obtained, it was calculated that average annual settlement price is lower than the contract price by about $0.20 \mathrm{PLN} \times \mathrm{GJ}^{-1}$, which in case of the analysed company may translate into an average daily loss of about 700 PLN.

\section{KEY WORDS}

forest biomass, transport, fuel value, ash content, forest woodchips, woodchip prices

\section{INTRODUCTION}

Apart from the energy policies (Polityka energetyczna... 2009), an important document that impacts the quantity of energy biomass is the 'National Forest Policy' whose aim is to increase the forest coverage of Poland to $30 \%$ up to 2020 and to $33 \%$ after 2050 . According to the Raport o stanie lasów w Polsce (2014), currently, the forest coverage in Poland is $29.4 \%$, whereas that in the surrounding countries (Latvia, Belarus, the Czech Republic, Slovakia, Germany) is above $30 \%$ (GUS 2013). The research realised and study works indicate that the rational forest coverage for Poland because of the structure of land use and maintenance of environment at the present stage of civilisation should be about $33-34 \%$. Increasing the forest coverage, apart from the environmental and ecological aspects, directly impacts the supply of lumber and biomass intended for energy production (Gołos and Kaliszewski 2013; Kaliszewski and Gołos 2014). 
Technologies that transform biomass into heat and electric energy are currently amongst the cheapest and most environment friendly. This thesis is backed by a large number of authors who analysed the utilisation of forest biomass for energy production (Grilli et al. 2015). However, in this case, the problem is the size of available resource base and the need to take the transport into consideration (Roszkowski 2008, 2012).

There are also many other barriers that impact the ease with which the biomass may be utilised and the growth of its market. Amongst such barriers mentioned is the lack of forecast for share of forestrelated biomass (including lumber) that could be feasibly used for energy creation in the forecasts up to 2020. According to the research of Płotkowski (2007) and different simulations performed for three different scenarios, it may be assumed that the quantity of forest biomass that can be used for energy production is somewhere between 11 and 16 million $\mathrm{m}^{3}$. These are, however, theoretical values that, when taking the availability of forest biomass into account, decrease to about 3-5 million $\mathrm{m}^{3}$. Zajączkowski (2013) forecasts that the theoretical lumber availability for energy production in the forests shall be 7.94 million $\mathrm{m}^{3}$ in 2021 and shall reach 8.91 million $\mathrm{m}^{3}$ in 2031, where the energy small wood and logging residue will be about 3.76 and 4.21 million $\mathrm{m}^{3}$ (respectively).

According to the Ordinance of the Minister of Economy, dated 18 October 2012 (Rozporządzenie 2012), the renewable energy sources do not include electricity or heat produced from full-value wood. This provision secures the valuable wood resource being used as fuel and, at the same time, results in interest in wood resources that were used to a small extent up to this point. This means that logging residue and biomass are mostly acquired during cutting activities. Creation of chips from such material is, however, burdened by a number of problem. The most crucial problems are the high degree of dispersal of biomass in forests, low yields and high content of green mass. This results in higher acquisition costs for the chips. Attention should also be given to the type of material from which the chips are formed and the resultant energy. The characteristics of woodchips are presented in Table 1.

As with all types of business activity, also in this case, all the business entities involved in the process of acquisition, transport and burning of the material must achieve an acceptable level of economic gains. Many of the characteristics of this sector results in a situation that not all the entities present in the individual segments of the sector achieve the expected profit. In most cases, this is due to the circumstances beyond the control or any choice of the companies. Such factors include dispersal of material on large areas, low 'density' of the material in the forest, location of power plants, high share of transport costs (large distances) and variability of physical and chemical characteristics of chips (fragment size, water content, ash content, hydrogen content, sulphur content, fuel value).

Owing to the location and dispersal of forests, the main type of transport used for chips is vehicular transport. During the past years, this type of transport has developed significantly and the transport work realised by this segment has increased many fold (Talbot and Suadicani 2006; Asikainen 2010; Pieriegud 2015).

Table 1. Selected characteristics of logging residues (Hałuzo and Musiał 2004)

\begin{tabular}{|c|c|c|c|c|c|}
\hline Details & Unit & Branch chips & Whole-tree chips & Trunk chips & Stump chips \\
\hline Water content (fresh material) & $\%$ & $50-60$ & $45-55$ & $40-55$ & $30-50$ \\
\hline Fuel value & $\mathrm{MJ} \times \mathrm{kg}^{-1}$ s.m. & $18.5-20$ & $18.5-20$ & $18.5-20$ & $18.5-20$ \\
\hline Fuel value of fresh material & $\mathrm{MJ} \times \mathrm{kg}^{-1}$ & $6-9$ & $6-9$ & $6-10$ & $6-11$ \\
\hline Bulk density & $\mathrm{kg} \times \mathrm{m}^{-3}$ & $250-400$ & $250-350$ & $250-350$ & $200-300$ \\
\hline Energy per volume unit & $\mathrm{MWh} \times \mathrm{m}^{-3}$ & $0.7-0.9$ & $0.7-0.9$ & $0.7-0.9$ & $0.8-1.0$ \\
\hline Ash content & $\%$ dry content & $1-3$ & $1-2$ & $0.5-2$ & $1-3$ \\
\hline Hydrogen content & $\%$ dry content & $6-6.2$ & $5.4-6$ & $5.4-6$ & $5.4-6$ \\
\hline Sulphur content & $\%$ dry content & $<0.05$ & $<0.05$ & $<0.05$ & $<0.05$ \\
\hline Nitrogen content & $\%$ dry content & $0.3-0.5$ & $0.3-0.5$ & $0.3-0.5$ & $0.3-0.5$ \\
\hline
\end{tabular}


Lisowski et al. (2015) stated that biomass should be transported in a compacted form, when analysing the form and density of energy biomass. But, as other authors point out, for example, Baum et al. (2012), full utilisation of energy biomass for the creation of the socalled 'green energy' may be achieved only by proper organisation of the biomass market (Rentizelas 2009), starting at the level of individual communes or districts. Jasiulewicz (2006) in his research pointed to the lack of economic efficiency of burning biomass in highly concentrated power plants (high costs of long-distance transport and negative environmental impact). He indicated the need to create local markets for biomass and local logistic centres.

From the viewpoint of the recipient of the chips - the power plant - the most crucial parameter of the material is the fuel value that is directly related to the water content of the material. The water content, in turn, is dependent on environmental conditions and, to a large extent, on the season in which the chips were acquired. The prices that the power plant is willing to pay is the result of these parameters. But is the supplier able to impact the physical parameters of the material supplied? - The impact is very limited. Therefore, should the supplier bear the costs related to lower parameters of the material that are beyond its control?

The answer to these questions must be preceded by the explanation of how determined is the price of the energy fuel in the form of the chips. The contract between the recipient (power plant) and the supplier of the chips determines the basic price for supplying $1 \mathrm{GJ}$ of energy. This value may be corrected (only downwards) if the quality parameters of the supplied biomass are below the threshold values. These parameters are fuel value, water content, sulphur content, chloride content and ash content. The amount paid for the delivery on a given day is based only on the weight of the chips. After analysing their actual water content, fuel value and content of unnecessary substances, the price is corrected and final settlement is realised at the next delivery or at the end of a given month. The rate paid for the supplied energy material is not dependent on the distance that the material travelled. This issue, if it is possible, should be negotiated when the basic rate of the contract is determined.

There is a certain possibility of increasing the parameters of the chips by drying (Gendek and Głowacki
$2008,2009)$. However, here we can only analyse natural drying - without adding additional energy, as such approach would make impossible achieving favourable financial results. Many suppliers use favourable conditions and stores the material in open yards.

This work aims to assess the physical parameters of woodchips during a calendar year and their impact on prices on the industrial market in settlements with a power plant.

\section{Material AND methods}

The subject of the analysis was information originating in a period from August 2013 to April 2015 which covered 252 days of chips deliveries by a single company to the power plant. Owing to the maintenance works in the power block fuelled by the biomass, there were no deliveries in July.

The research material was woodchips acquired during cleaning of logging areas. The residue, that is, branches of trees of different forest species, assessed in accordance with size/quality norms as small wood, was acquired in forests of the North-Eastern Poland, mostly from the Podlaskie, Warmińsko-Mazurskie and the Northern part of the Mazowieckie regions. The residue was fragmented using Bruks $805 \mathrm{C}$ machines installed on the chassis of a forwarder for a period of two to six months after logging.

Timber acquisition during the months when the data were collected was realised using varied methods: using machinery or by a mixed machinery/manual method. Regardless of the method of acquisition, chipping was realised directly in the forest or the residues were extracted using a self-loading tractor, piled at the exit road and chipped there.

Transport from forests to the power plant (average distance of $300 \mathrm{~km}$ ) was realised using trailer trucks with capacity of $90 \mathrm{~m}^{3}$ equipped with movable floors. Exemplary routes of transport vehicles and geographical location of forests and the power plant are presented in Figure 1.

The chips were delivered to the power plant located in the central area of the country. Out of every transport, a sample of about 101 was taken. Samples from all deliveries during a given day were mixed in order to ensure uniformity of material. Such pre- 
pared samples were analysed in order to assess their water content, fuel value, sulphur content and ash content in the laboratory of the power plant. There was a protocol created for every day that allowed for the identification of date for a given supply, the physical parameters of the chips and the related basic and settlement prices.

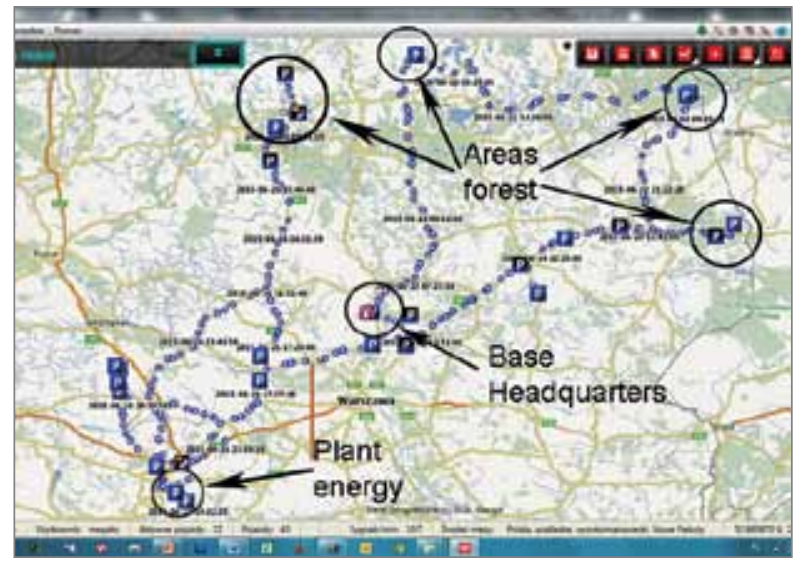

Figure 1. The route of an exemplary transport vehicle and the location of forests in relation to the base and the power plant

Table 2. Requirements for forest biomass established by the power plant

\begin{tabular}{|l|c|c|c|c|}
\hline \multicolumn{1}{|c|}{ Parameter } & Symbol & Unit & $\begin{array}{c}\text { Min/ } \\
\max \end{array}$ & Value \\
\hline Fuel value & $c v_{g}$ & $\mathrm{GJ} \times \mathrm{Mg}^{-1}$ & $\min$ & 7.0 \\
\hline Water content & $w_{g}$ & $\%$ & $\max$ & $\begin{array}{c}50 \text { (Apr-Sep) } \\
60 \text { (Oct-Mar) }\end{array}$ \\
\hline $\begin{array}{l}\text { Sulphur } \\
\text { content }\end{array}$ & $z_{s g}$ & $\%$ & $\max$ & 0.3 \\
\hline Ash content & $z_{p g}$ & $\%$ & $\max$ & 5.0 \\
\hline $\begin{array}{l}\text { Basic price } \\
\text { (weight) }\end{array}$ & $p_{p m}$ & $\mathrm{PLN} \times \mathrm{Mg}^{-1}$ & - & 193.50 \\
\hline $\begin{array}{l}\text { Basic price } \\
\text { (fuel value) }\end{array}$ & $p_{p c}$ & $\mathrm{PLN} \times \mathrm{GJ}^{-1}$ & - & 21.50 \\
\hline
\end{tabular}

Price decreased for exceeding contractual limits of

\begin{tabular}{|l|c|c|c|c|}
\hline Fuel value & $p_{c j}$ & $\mathrm{PLN} \times \mathrm{GJ}^{-1}$ & - & $1.08-1.12$ \\
\hline Water content & $p_{w j}$ & $\mathrm{PLN} \times \mathrm{GJ}^{-1}$ & - & $1.08-1.12$ \\
\hline $\begin{array}{l}\text { Sulphur } \\
\text { content }\end{array}$ & $p_{s j}$ & $\mathrm{PLN} \times \mathrm{GJ}^{-1}$ & - & $1.08-1.12$ \\
\hline Ash content & $p_{p j}$ & $\mathrm{PLN} \times \mathrm{GJ}^{-1}$ & - & $1.08-1.12$ \\
\hline
\end{tabular}

The procedures used to assess the water content, heat of combustion, fuel value, sulphur content and ash content were based on norms PN-EN 13183-1:2004, PNISO 1928:2002, PN-G-04584:2001, PN-EN 15289:2011, PN-EN ISO 16994:2015 and PN-ISO 1171:2002.

The distance between the forests and the power plant (accuracy $\pm 1 \mathrm{~km}$ ) was analysed based on the data from the vehicle fleet database of one of the chips suppliers and the analysis of parameters of chips was based on the data agreed and signed in the contract between the supplier and the energy company. Detailed requirements for energy chips supplied to the power plant are given in Table 2.

\section{Determination of basic and settlement value of delivery}

The values for individual deliveries of chips is based on weight and physical parameters of the chips, which include fuel value, water content, sulphur content and ash content. The threshold value for water content of the chips, as given in Table 2, is dependent on the delivery date. During the fall, winter and early spring months, because of precipitation, the power plant allows higher water content of about $60 \%$, which makes it easier for the supplier to meet the required water content level.

The value of chips at the delivery date is determined roughly, only on the basis of their weight and basic price $\left(p_{p m}\right)$ agreed in the contract in accordance with equation 1 .

$$
K_{i}=m_{i} \times p_{p m}
$$

where

$K_{i}$ - the basic value of $i$ th delivery [PLN],

$m_{i}$ - the weight of the ith delivery $[\mathrm{Mg}]$,

$p_{p m}-$ the basic price 'weight' $\left[\mathrm{PLN} \times \mathrm{Mg}^{-1}\right]$.

The biomass is subsequently subjected to detailed analysis in the laboratory of the power company, in order to measure the individual parameters. In case of noncompliance with the values set in the contract, the power plant corrects the value of the realised delivery, and the difference with the 'basic' value is settled when the next delivery is settled. The price and settlement value of $i$ th delivery are established on basis of equations 2 and 3. 


$$
\begin{gathered}
p_{p r i}=p_{p c}-p_{w j}-p_{c j}-p_{s j}-p_{p j} \\
K_{r i}=m_{i} \times c v_{i} \times p_{p r i}
\end{gathered}
$$

where

$p_{\text {pri }}$ - the delivery settlement price $\left[\mathrm{PLN} \times \mathrm{GJ}^{-1}\right]$,

$K_{r i}$ - the settlement value of $i$ th delivery [PLN],

$c v_{i}$ - the fuel value of chips in the $i$ th delivery $\left[\mathrm{GJ} \times \mathrm{Mg}^{-1}\right]$,

$p_{p c}$ - the basic price 'fuel' $\left[\mathrm{PLN} \times \mathrm{Mg}^{-1}\right]$,

$p_{w j}$ - the decrease in unit price for excessive water content $\left[\mathrm{PLN} \times \mathrm{GJ}^{-1}\right]$,

$p_{c j}-$ the decrease in the unit price for lower fuel value $\left[\mathrm{PLN} \times \mathrm{GJ}^{-1}\right]$,

$p_{s j}-$ the decrease in the unit price for sulphur content $\left[\mathrm{PLN} \times \mathrm{GJ}^{-1}\right]$,

$p_{p j}$ - the decrease in the unit price for ash content $\left[\mathrm{PLN} \times \mathrm{GJ}^{-1}\right]$.

As visible in equations 2 and 3, the basis for final settlement are the characteristic values for the biomass and the unit price is related to the fuel value of the chips and not directly to their weight. The basic unit price (per one GJ) is reduced if the supplier fails to meet the threshold levels of the quality parameters. The rule of determining the final settlement price for the delivered chips (in relation to their fuel value) is price reduction, if the parameters of the chips are lower than the ones defined in the contract. The mechanism does not award (price increase) the supplier in cases where the chips are significantly better, that is, with low water content and higher fuel value.

Using the above-defined values, it is possible to establish the average weighted delivery price $\left(p_{s r}\right)$ in the analysed period:

$$
p_{s r}=\frac{\sum_{i=1}^{n} p_{p r i} \times m_{i} \times c_{v i}}{\sum_{i=1}^{n} m_{i} \times c_{v i}} \quad[\text { PLN/G] }]
$$

\section{Results AND discussion}

On basis of analysis of randomly chosen 186 deliveries of chips, it was established that the average transport distance was $341.25 \mathrm{~km}(\mathrm{SD}=65.12)$ and was between 188 and $499 \mathrm{~km}$.

Average water content and the resultant fuel value of the chips supplied to the power plant is directly re- lated to the atmospheric conditions and the month of delivery. The basic statistics are presented in Table 3.

\begin{tabular}{|c|c|c|c|c|c|c|}
\hline Month & 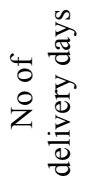 & 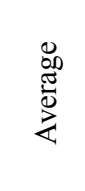 & $\underset{\Xi}{\stackrel{\Xi}{\Xi}}$ & 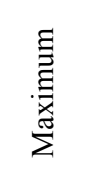 & 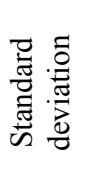 & 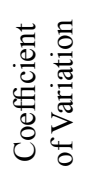 \\
\hline & \multicolumn{6}{|c|}{ Water content $[\%]$} \\
\hline January & 35 & 46.58 & 34.20 & 56.10 & 5.35 & 11.49 \\
\hline February & 25 & 47.12 & 36.60 & 54.60 & 4.49 & 9.52 \\
\hline March & 30 & 45.94 & 35.80 & 59.10 & 4.57 & 9.95 \\
\hline April & 24 & 43.77 & 36.30 & 50.10 & 3.92 & 8.95 \\
\hline May & 17 & 41.23 & 35.70 & 57.80 & 5.29 & 12.83 \\
\hline June & 8 & 35.56 & 32.90 & 39.90 & 2.72 & 7.65 \\
\hline July & 0 & - & - & - & - & - \\
\hline August & 8 & 39.24 & 29.10 & 55.60 & 8.95 & 22.80 \\
\hline September & 8 & 27.74 & 23.00 & 31.30 & 3.00 & 10.82 \\
\hline October & 48 & 36.04 & 26.00 & 46.10 & 5.59 & 15.52 \\
\hline November & 29 & 37.83 & 25.70 & 50.80 & 7.54 & 19.94 \\
\hline \multirow[t]{2}{*}{ December } & 20 & 43.65 & 31.30 & 55.70 & 6.63 & 15.19 \\
\hline & \multicolumn{6}{|c|}{ Fuel value $\left[\mathrm{GJ} \times \mathrm{Mg}^{-1}\right]$} \\
\hline January & 35 & 8.74 & 6.21 & 10.68 & 1.11 & 12.75 \\
\hline February & 25 & 8.71 & 7.30 & 11.13 & 0.98 & 11.31 \\
\hline March & 30 & 8.81 & 6.24 & 10.37 & 0.87 & 9.82 \\
\hline April & 24 & 9.26 & 8.11 & 10.94 & 0.83 & 8.93 \\
\hline May & 17 & 10.01 & 6.28 & 11.48 & 1.23 & 12.33 \\
\hline June & 8 & 10.92 & 8.82 & 12.05 & 1.12 & 10.25 \\
\hline July & 0 & - & - & - & - & - \\
\hline August & 8 & 10.12 & 6.93 & 12.53 & 2.05 & 20.26 \\
\hline September & 8 & 12.94 & 12.40 & 14.19 & 0.55 & 4.25 \\
\hline October & 48 & 11.10 & 9.14 & 13.65 & 1.23 & 11.12 \\
\hline November & 29 & 10.61 & 7.59 & 13.24 & 1.66 & 15.63 \\
\hline December & 20 & 9.45 & 7.04 & 11.85 & 1.32 & 13.96 \\
\hline
\end{tabular}

Table 3. Descriptive statistics for water content and fuel value of chips

The lowest average water content $(27.74 \%$; $\mathrm{SD}=3.00)$ and the highest fuel value $\left(12.94 \mathrm{GJ} \times \mathrm{Mg}^{-1}\right)$ were observed in case of chips supplied to the pow- 
er plant in September. Owing to the fact that timber harvesting took place a few months before chipping, the forest biomass in form of branches and treetops rested on the ground during the summer season and decreased its water content naturally. From October onward, the water content increased - lower temperature, rainfall and snowfall - down to the maximum water content in February, 47.12\% $(\mathrm{SD}=4.47)$. From March to September (spring/summer), the water content decreased and the fuel value increased. The fuel value of chips delivered to the power plant was similar to the values determined by, amongst others, Gendek and Zychowicz (2014), Günther et al. (2012) or Phanphanich and Mani (2009), which at low humidity (5-7\%) may achieve about $18 \mathrm{GJ} \times \mathrm{Mg}^{-1}$.

The recurring character of changes in water content and fuel value indicates that the best period for the chips suppliers are months from June to November, when the material is characterised by the lowest average water content $(<40 \%)$ and highest fuel value $(>10$ $\mathrm{GJ} \times \mathrm{Mg}^{-1}$ ). This relation is shown in Table 3 (grey background).

The problem here is the varied seasons in the year and the heating season. During the summer months, the power plants have lower demand for chips. In the analysed case, the average size of daily deliveries to the power plant was $270 \mathrm{Mg}$ in June and $145 \mathrm{Mg}$ in August, while in the December-February period, it was on an average $340-370 \mathrm{Mg}$ a day.

The threshold value for water content determined between the supplier and the recipient and the minimum threshold value for fuel value (Tab. 2) regardless of the month are values that the supplier is able to meet. Amongst the 252 delivery days analysed, there were eight instances of exceeding the above-mentioned parameters, including five cases of too low fuel value and three cases of excessive water content in the chips.

The obtained results made possible to determine the relationship between the fuel value of the chips and their humidity (Fig. 2), that is, the following equation:

$$
y=-0.2139 x \times 18.7222 ; \quad r^{2}=0.9610
$$

Another important parameters controlled by the power plant are the content of sulphur and ash. The average sulphur content in individual months was between $0.016 \%$ and $0.022 \%$ (minimum 0.01 ; maximum
0.027) and did not exceed the upper threshold value of $0.3 \%$ (Fig. 3), which corresponds to biomass sulphur content of $0.02 \%$, determined by Komorowicz et al. (2009).

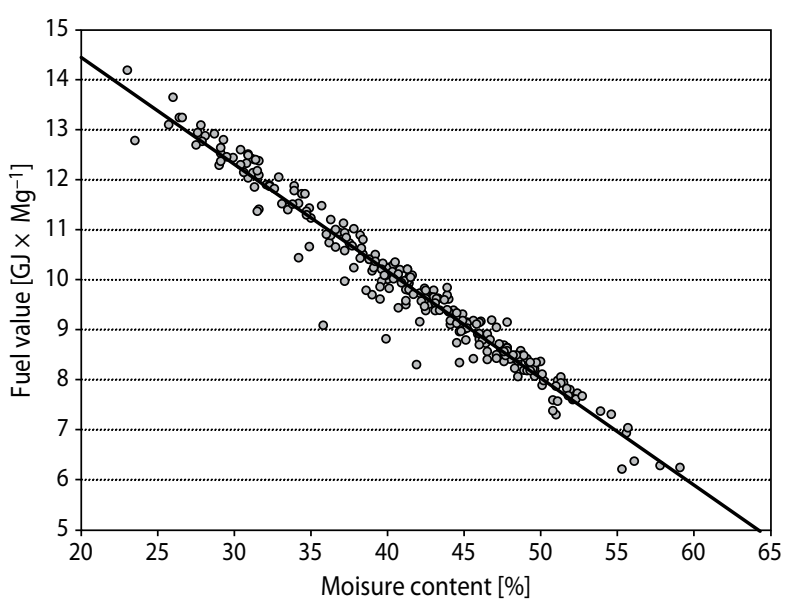

Figure 2. Relationship between the fuel value of forest wood chips and their humidity

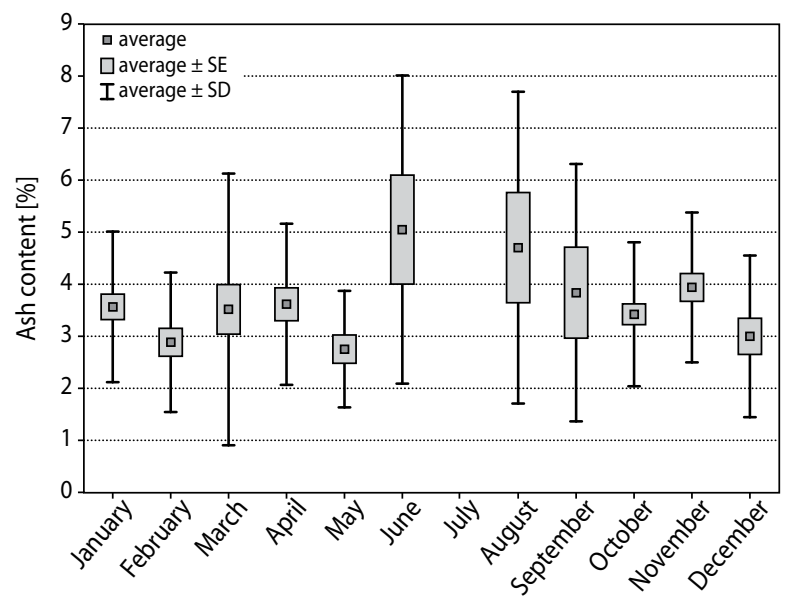

Figure 3. Sulphur content in chips in individual months

An important parameter from the viewpoint of the supplier, which results in decrease in price for exceeding the threshold values is the ash content (Fig. 4). The average ash content in the analysed chips, in most cases, was about $3-4 \%$. This is about 1 percentage point above the values present in the literature for branch chips (Phanphanich M., Mani S. 2011) and about 1-2 percentage points above the values given for chips acquired from whole trees (Tab. 1). In the analysed period, 
there were 29 days ( $11.5 \%$ of all deliveries) of deliveries where the value exceeded the threshold. The highest values were recorded during the summer months (June and August), whereas the average ash content in June was above $5 \%$ and close to that value in August. During the above-mentioned months, the largest diversity of measured values was observed.

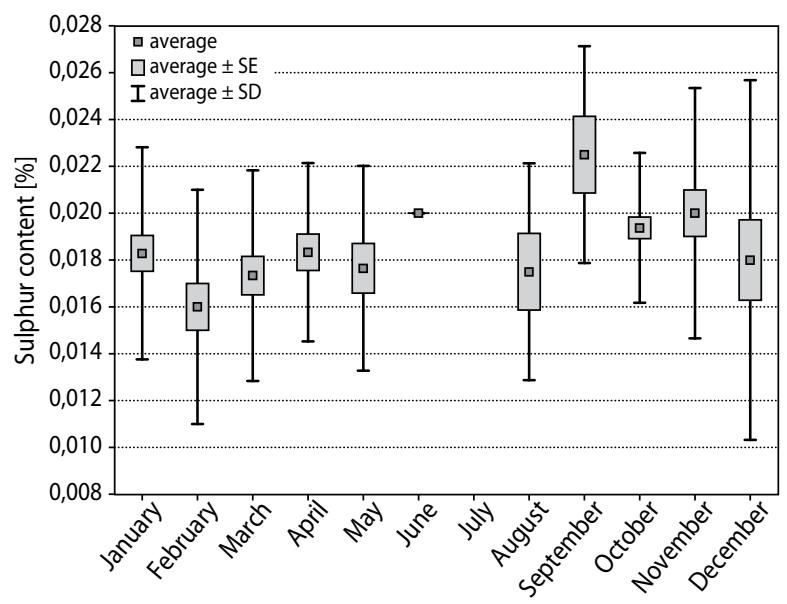

Figure 4. Ash content in chips in individual months

Ash content in chips is a parameter that may be under certain degree of control by the supplier if the proper method of works during chipping is selected. It may be assumed that the excess ash comes mostly from mineral contaminants, which are present in the form of sand in the forest floor and tree bark and are acquired during unskilful grabbing of the logging residue.

Taking into consideration the contractual and the measured parameters of chips supplied to the power plant after accounting for the deductions for exceeding the norms, the average settlement price for GJ of energy is calculated. Results are presented in Figure 5. Depending on the month of deliveries, the settlement price is from less than 10 to more than a few dozen groszy (1/100 PLN) worse than the basic price. The largest difference is present in June and August, when the number of deliveries with excessive ash content was the largest. These are, however, summer months where the demand for energy is lower and the daily deliveries are reduced in comparison to other months.

Interesting conclusions may be drawn by comparing the above-mentioned data. The data in Table 3 and on Figures 2 and 3 shows that the average monthly values of parameters of the analysed biomass exceed the threshold levels only in a few instances.

Average monthly fuel values meet the contractual requirements every month and exceed the minimal required values. Similarly, the sulphur content never exceeded the threshold level. Only in the case of ash content, there was one case of exceeding the threshold value in June. The analysis of the average values shows that the quality of the provided biomass is satisfactory. Therefore, why was it so (which is shown in the graph of Fig. 5) that the settlement price was lower than the basic contractual price through the whole year. This situation is due to the method that is used for calculating the settlement price.

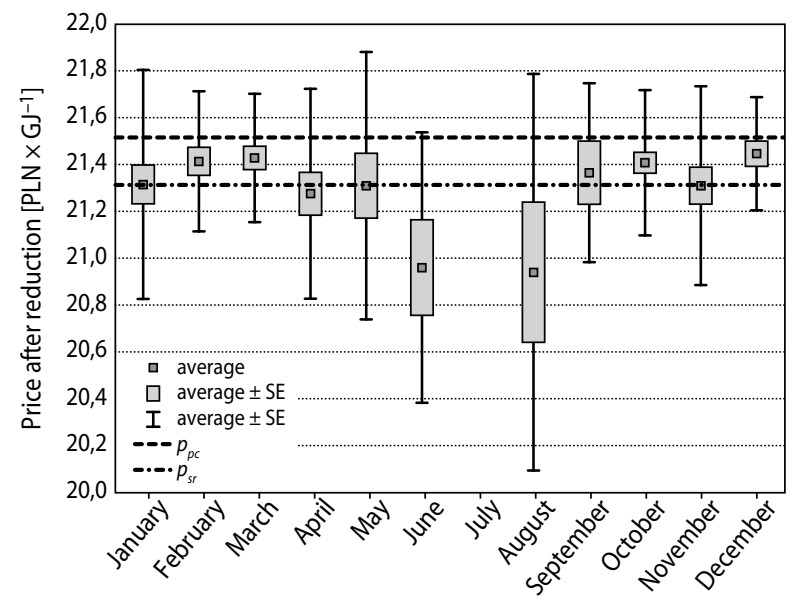

Figure 5. Unit price after the reduction for exceeding the norms $\left[\mathrm{PLN} \times \mathrm{GJ}^{-1}\right] ; p_{p c}$, basic price; $p_{s r}$, average settlement price

The settlement price is related to daily deliveries and may be corrected only downwards if the required parameters are not met by the supplier. As it was mentioned earlier, there is no award for deliveries of higher quality. This system means that every negative deviation from the set values decreases the settlement price and that there is no mechanism that could increase the said price. In such a case, determination of the settlement price on the basis of average monthly values of quality parameters is not the correct mechanism.

When assessing the settlement system between the suppliers and the recipients of the forest woodchips, we have to state that in many cases, it works to the detri- 
ment of the supplier, resulting in the basic price being lowered in all the analysed months.

In the analysed case of a single supplier (Fig. 5), the average annual settlement price for $1 \mathrm{GJ}$ of energy was about 0.2 PLN lower than the contract price, which translates into daily loss for the supplier of about 700 PLN and during a month (depending the number of days with deliveries) from a few thousand PLNs to (in some extreme cases) about 14,000 PLN.

\section{Conclusions}

In the analysed period, there were $11.5 \%$ of all deliveries where the values exceeded the contractual threshold. However, it turned out that the average price in every analysed months was lower than the one agreed with the recipient.

Sulphur content did not impact the base price in settlements between the supplier and the recipient as the threshold levels have not been exceeded.

The problem is the excessive ash content. There is a need for further research concerning factors impacting the ash content in the chips: contents of the forest biomass (wood, needles, bark) and contaminants (sand, forest flooring).

The settlement system used for the delivered chips is disadvantageous for the suppliers. It allows for the price being lowered if some of the parameters are not met but does not foresee a method for increasing the price.

The analysed method of settlement between the supplier and the recipient of forest chips does not take into consideration the distance between the location where the material is acquired and the location of the recipient. If this is possible, the transport distance should be taken into consideration when setting the basic price.

\section{References}

Asikainen A. 2010. Simulation of stump crushing and truck transport of chips. Scandinavian Journal of Forest Research, 25 (3), 245-250. DOI: 10.1080/02827581.2010.488656

Baum R., Wajszczuk K., Wawrzynowicz J. 2012. Modelowe rozwiązanie logistyczne dla lokalnego ryn- $\mathrm{ku}$ biomasy [Logistic model project for the local biomass market]. Logistyka, 4, 846-854 [in Polish with English abstract].

Gendek A., Głowacki S. 2008. Badania wstępne suszenia zrębków sosnowych przeznaczonych na cele energetyczne [Preliminary studies drying pine wood chips intended for energy purposes]. In: Tendencje i problemy techniki leśnej w warunkach leśnictwa wielofunkcyjnego (eds.: H. Różański, K. Jabłoński). Uniwersytet Przyrodniczy w Poznaniu, 197-203 [in Polish].

Gendek A., Głowacki S. 2009. Convectional drying of chips for energy purposes. Annals of Warsaw University of Life Sciences - SGGW. Agriculture, 53, 67-72.

Gendek A., Zychowicz W. 2014. Investigations on the calorific value of forest chips. Annals of Warsaw University of Life Sciences - SGGW. Agriculture, 63, 65-72.

Gołos P., Kaliszewski A. 2013. Biomasa leśna na cele energetyczne [Forest biomass for energy purposes]. Wydawnictwo IBL, Sękocin Stary, Poland [in Polish].

Grilli G., Garegnani G., Poljanec A., Ficko A., Vettorato D., De Meo I., Paletto A. 2015 Stakeholder analysis in the biomass energy development based on the experts' opinions: the example of Triglav National Park in Slovenia. Folia Forestalia Polonica, Series A - Forestry, 57 (3), 173-186. DOI: 10.1515/ ffp-2015-0017.

GUS 2013. Leśnictwo 2013. Informacje i opracowania statystyczne [GUS 2013. Forestry 2013. Statistical information and reports]. Główny Urząd Statystyczny, Warszawa [in Polish].

Günther B., Gebauer K., Barkowski R., Rosenthal M., Bues C.T. 2012. Calorific value of selected wood species and wood products. European Journal of Wood and Wood Products, 70 (5), 755-757.

Hałuzo M., Musiał R. 2004. Ocena zasobów i potencjalnych możliwości pozyskania surowców dla energetyki odnawialnej w województwie pomorskim [Evaluation of resources and the potential to obtain raw materials for renewable energy in Pomorskie]. Biuro Planowania Przestrzennego w Słupsku, Słupsk [in Polish].

Jasiulewicz M. 2006. Problem centrów logistycznych w obrocie biomasą [Logistics centres' problems in 
biomass market]. Biuletyn PAN, Komitet Przestrzennego Zagospodarowania Kraju, 225, 157-164 [in Polish].

Kaliszewski A., Gołos P. 2014 Predictions on availability and possibilities of the use of wood for energy purposes in Europe and in Poland. Folia Forestalia Polonica, Series A - Forestry, 56 (2), 71-78. DOI: 10.2478/ffp-2014-0007

Komorowicz M., Wróblewska H., Pawłowski J. 2009. Skład chemiczny i właściwości energetyczne biomasy z wybranych surowców odnawialnych [Chemical composition and energetic properties of biomass from selected renewable resources]. Ochrona Środowiska i Zasobów Naturalnych, 40, 402-410 [in Polish].

Lisowski A., Kostrubiec M., Dąbrowska-Salwin M., Świętochowski A. 2015. Cechy peletów z biomasy roślinnej w aspekcie logistyki dostaw [Properties of pellets from plant biomass of the logistic supply]. Logistyka, 5, 351-356 [in Polish with English abstract].

Mobini M., Sowlati T., Sokhansanj S. 2011. Forest biomass supply logistics for a power plant using the discrete-event simulation approach. Applied Energy, 88, 1241-1250. DOI:10.1016/j.apenergy.2010.10.016

Phanphanich M., Mani S. 2009. Drying of pine residues. BioResources, 5 (1), 108-121.

Phanphanich M., Mani S. 2011. Impact of torrefaction on the grindability and fuel characteristics of forest biomass. Bioresource Technology, 102 (2), 1246-1253. DOI:10.1016/j.biortech.2010.08.028

Pieriegud J. 2015. Polski rynek usług transportu samochodowego i kolejowego - bilans dziesięciolecia w Unii Europejskiej [Road and rail transport market in poland - the balance of a decade in the European Union]. Logistyka, 1, 8-12 [in Polish with English abstract].

Płotkowski L. 2007. Bilans biomasy z lasów, stan obecny i prognoza średnio- i długookresowa [The balance of biomass from forests, current situation and forecast the medium- and long-term]. In: Biomasa dla elektroenergetyki i ciepłownictwa. Szanse i problemy. Wydawnictwo Wieś Jutra, Warszawa [in Polish].

PN-EN 13183-1:2004. 2004. Wilgotność sztuki tarcicy. Część 1: Oznaczenie wilgotności metodą suszarkowo-wagowa. Polski Komitet Normalizacyjny, Warszawa.
PN-ISO 1928:2002. 2002. Paliwa stałe. Oznaczanie ciepła spalania metoda spalania w bombie kalorymetrycznej i obliczanie wartości opałowej. Polski Komitet Normalizacyjny, Warszawa.

PN-EN 15289:2011. 2011. Biopaliwa stałe. Oznaczanie zawartości siarki całkowitej i chloru. Polski Komitet Normalizacyjny, Warszawa.

PN-EN ISO 16994:2015-06. 2015. Biopaliwa stałe. Oznaczanie zawartości siarki całkowitej i chloru. Polski Komitet Normalizacyjny, Warszawa.

PN-G-04584:2001. 2001. Paliwa stałe. Oznaczanie zawartości siarki całkowitej i popiołowej automatycznymi analizatorami. Polski Komitet Normalizacyjny, Warszawa.

PN-ISO 1171:2002. 2002. Paliwa stałe. Oznaczanie popiołu. Polski Komitet Normalizacyjny, Warszawa.

Polityka energetyczna Polski do 2030 roku. 2009. Załącznik do Uchwały nr 202/2009 Rady Ministrów. Dokument przyjęty przez RM w dniu 10 listopada 2009 r. Ministerstwo Gospodarki, Warszawa.

Raport o stanie lasów w Polsce 2013. 2014 [Report on the state of forests in Poland in 2013]. Dyrekcja Generalna Lasów Państwowych, Warszawa [in Polish].

Rentizelas A., Tolis A., Tatsiopoulos I. 2009. Logistics issues of biomass: The storage problem and the multi-biomass supply chain. Renewable and Sustainable Energy Reviews, 13, 887-894. DOI:10.1016/j.rser.2008.01.003

Roszkowski A. 2008. Biomasa kontra rolnictwo [Biomass versus agriculture]. Inżynieria Rolnicza, 10 (108), 201-208 [in Polish with English abstract].

Roszkowski A. 2012. Biomasa i bioenergia - bariery technologiczne i energetyczne [Biomass and bioenergy - technological and energetic barriers]. Problemy Inżynierii Rolniczej, 3 (77), 79-100 [in Polish with English abstract].

Rozporządzenie Ministra Gospodarki z dnia 18 października 2012 r. w sprawie szczegółowego zakresu obowiązków uzyskania i przedstawienia do umorzenia świadectw pochodzenia, uiszczenia opłaty zastępczej, zakupu energii elektrycznej i ciepła wytworzonych w odnawialnych źródłach energii oraz obowiązku potwierdzania danych dotyczących ilości energii elektrycznej wytworzonej w odnawialnym źródle energii. Dz.U. 2012, poz. 1229. 
Talbot B., Suadicani K. 2006. Road transport of forest chips: containers vs. bulk trailers. Forestry Studies, $45,11-22$.

Zajączkowski S. 2013. Prognozy pozyskiwania drewna w Polsce w perspektywie 20 lat oraz możliwości ich wykorzystania do szacowania zasobów drewna na cele energetyczne [Forecasts logging in Poland within 20 years and the possibility of their use for the estimation of wood resources for energy purpo- ses]. In: Biomasa leśna na cele energetyczne (eds.: P. Gołos, A. Kaliszewski). Wydawnictwo IBL, Sękocin, 21-31 [in Polish].

Zhang F., Johnson D., Sutherland J. 2011. A GIS-based method for identifying the optimal location for a facility to convert forest biomass to biofuel. Biomass and Bioenergy, 35, 3951-3961. DOI: 10.1016/j. biombioe.2011.06.006. 